Article

\title{
How to Teach Pre-Service Teachers to Make a Didactic Program? The Collaborative Learning Associated with Mobile Devices
}

\author{
Rebeca Soler Costa ${ }^{1} \mathbb{D}$, Marta Mauri Medrano ${ }^{1} \mathbb{(}$, Pablo Lafarga Ostáriz ${ }^{1}(\mathbb{D}$ and \\ Antonio-José Moreno-Guerrero 2,*(D) \\ 1 Department of Education Sciences, University of Zaragoza, 50009 Zaragoza, Spain; rsoler@unizar.es (R.S.C.); \\ mmauri@unizar.es (M.M.M.); 681742@unizar.es (P.L.O.) \\ 2 Department of Didactics and School Organization, University of Granada, 51001 Ceuta, Spain \\ * Correspondence: ajmoreno@ugr.es
}

Received: 3 April 2020; Accepted: 27 April 2020; Published: 6 May 2020

check for updates

\begin{abstract}
Today, pedagogical proposals are increasingly moving away from purely traditional approaches, with a proliferation of active methodologies in the teaching-learning processes. This research aims to find out the effectiveness of the collaborative method in mobile learning, as opposed to traditional methodology, for university students in the learning of the didactic program. The research methodology is quantitative, applying a quasi-experimental design with a control group and experimental group. The results show that the collaborative learning teaching method associated with mobile learning mainly increases motivation, the relationships between teachers and students, the relationships between students and content, the relationships between students and students, autonomy in learning, pedagogical collaboration between students, problem-solving, and the sense of time in the training process. It is concluded that the collaborative learning method associated with mobile learning is more effective for learning didactic programming than the traditional method.
\end{abstract}

Keywords: emerging methodology; educational innovation; mobile learning; collaborative learning; educational experimentation; university; students

\section{Introduction}

The presence of educational proposals that are more distant from traditional approaches is an increasingly clear trend [1]. Educational institutions have presented this new direction, a recent approach that distances itself from traditional and passive methods [2], through a commitment to more innovative teaching processes [3]. This orientation essentially responds to the positive impact that they generate on issues such as student training [4-9] or, linked to this, the social environment [10].

One of the educational practices that have been gaining the most recognition in recent times is what is known as collaborative learning [11]. This is an approach whose value has increased not only because of its innovative nature [12-14], but also because of its pedagogical implications [15]. The approach is based on the work of two or more people [16] —in this case, students—whose learning is the result of the individual and collective success of the group [17]. In this sense, it is developed in such a way that small workgroups have to solve academic problems [18], so that not only the result is important, but also the process.

The elements that make up this methodology are diverse. The didactic elements acquire a greater dimension, since they do not correspond to an individual mechanical task, but have to be one of the bases of the symbiosis between the members of the group [19]. Individuals' own skills become common when there is a group process towards the search for a goal, a key issue in learning that not 
only stays in the contents [20] or the improvement of work with information [21], but deepens and goes beyond. Only the achievement of related methodological principles will allow us to assume policies by the reality we want to improve.

This pedagogical practice, whose presence in higher education has increased significantly [22], reinforces human characteristics [23] that range from the exchange of experiences [24] to benefits in the state of mind during the process $[25,26]$. It should also be borne in mind that collaborative learning has a different burden from that of the cooperative one, delimited by previously defined roles, and, in this case, the importance of self-regulation [27] and the capacity of individuals to "play their role" within the group, something that occurs naturally [28] by the human condition itself, emerge.

Therefore, individual performance has a direct impact on the achievements of the rest [29], which is a distinctive feature of group work [30] compared to other methodologies, as well as joint problem solving [31] or the natural appearance of linguistic strategies, such as debates [32]. These facts support the sense of community, which is a relevant factor due to its repercussions on the functioning of the group [33,34] or the creation of study teams [35].

Functioning through collaborative learning also has less positive issues. Human interactions are complex and, therefore, require time to occur properly [36], as not all groups can learn the same thing. Individual and group commitment may be lacking [37] in the same group, and the desired success may not be achieved during that training process [38]. Students are diverse and each one learns at a different pace, which is why the teacher's role is essential if this methodology is to be used. Their previous pedagogical training must be sufficiently broad and effective [39] to be able to carry out a complex approach within classrooms, whose own complexity is evident because each one is unique.

Despite this, several studies show the potential of collaborative learning, such as the positive evaluation of students who work through it $[40,41]$ and their consequent motivation or attitude [42]. There are also repercussions derived from active participation in their learning [43], as well as the achievement and resolution of the educational challenges presented through group activities [44]. The improvement in personal communication $[45,46]$ and interpersonal skills is, logically, one of the most positive points of this collaborative methodology.

One of the strategies that has been most reinforced or that has accompanied the approaches to collaborative learning is what is known as mobile learning. Information and Communication Technologies (ICT) are a means associated with new pedagogical approaches, which is classified as an educational innovation. In this case, mobile learning and collaborative learning are closely linked. In fact, in recent years, the so-called Mobile Computer-Supported Collaborative Learning (MCSCL) has emerged. Although it will be discussed in more detail later on, this is the union of both proposals with didactic purposes, and its advantages in learning are positive, according to studies [47].

Firstly, mobile learning should be put into context, as its presence in scientific literature has increased significantly [48], as it is a real application of the union of the real world and the digital world $[49,50]$. It is a new approach that moves the media available through mobile devices to learning, especially in areas such as, but not limited to, higher education [51,52]. It is a clear commitment to new educational practices and the search for innovation $[53,54]$ in an educational context influenced by ICT. In this sense, it is important to consider how a transversal change is required, from the management of educational centers to the teachers themselves [55], who also have the opportunity to rethink teaching processes [56].

Mobile learning is one of the major evidences that expose the union of ICT and education. Its conception, based on technological devices whose presence in daily life is already natural, has promoted the emergence of a great literary interest in its didactic applications. The relationship between the use of technology and the benefits and impact on students is a scientific quest that has been developed worldwide in recent decades, with a special focus on university students [57]. Some studies have already been interested in this orientation, specifically concerning its effectiveness on students [58]. 
Its emergence has responded, as explained above, to two key factors: Access to it and the real possibilities of its use. Over the last decade, the publication of studies on its use has grown, contributing to the idea that its true potential has yet to be achieved [59]. One of the reasons for this is that mobile learning can provide new learning practices that would not be possible without it, a complex combination that combines the real world with the digital world [60]. In addition, the use of mobile devices can provide significant insights into real study habits, such as actual study routines and their usefulness [61].

Instant messaging, as an established habit, is also a learning path that encompasses this methodology [62,63]. Chatbots, as a parallel tool to Artificial Intelligence (AI) available on mobile devices, are another variable to be taken into consideration, since a subsequent analysis of conversations with students [64] could also provide relevant information. New strategies are available within mobile learning that can reinforce its application in the classroom, especially to support or control the different factors relevant to self-regulated learning [65]; in other words, taking the necessary steps to achieve and develop good practices [66].

It should be said that the negative aspects are based on the approaches through these means. At least until 2016, the standards could be significantly improved [67]. This is complemented by students' resistance to the use of these mobile devices for learning, the main reasons for which are that they do not see clear differences from traditional study or that the digital resources are simply based on passing on computer content in the format of a smartphone [68]. This is why some studies recommend not only focusing on content, but also on contexts, such as emotional and social ones, encouraging students to play an active role and not just receive information, and encouraging interaction to make learning more challenging [69].

The nuances provided in the previous paragraphs are based on a key fact: The adaptation of mobile devices to the educational environment has been a quest that dates back even to the twentieth century. Now, through cataloguing as well as mobile learning, new evidence continues to be researched to support its application. Various published meta-analyses clarify all of this, from those that focus on how it has been taken into consideration in the field of nursing [70] to those that focus on less distant periods but provide perspectives on trends in this field over the last decade [71].

Taking up the union of collaborative learning and mobile learning again, the MCSCL is an approach that combines a more pedagogical approach with a more technological one and whose presence has become more relevant in recent times [72]. Under this conceptualization, learning is produced that combines the advantages of collaborative learning, which is important in terms of how it is developed [73], and active regulation of learning through mobile devices [69]. In this case, aspects such as guidance, interpersonal interaction with technology, and interpersonal access to more contextualized learning are very important [74].

If we look at the MCSCL from a perspective, it is an evolutionary step, based on current technological development, of Computer-Supported Collaborative Learning (CSCL), a predecessor whose rise during the first decade of the 21st century was produced by the best, appreciated for student motivation or self-regulation, although always taking into consideration the necessary coordination required by this educational approach [75]. One of these factors is the area of knowledge in which this strategy is applied, since its effectiveness is usually more associated with fields such as engineering, science, or social sciences, as well as with stages such as university education [76]. In short, this is a new step forward between ICTs and educational improvement, which is essential for society [77].

The definition and explanation of the methodologies called mobile learning and collaborative learning were fundamental to the approach of this article. Although, on this occasion, the MCSCL cannot be considered to be developed in a pure form, it is important to be able to understand the pedagogical context in which this work is carried out. In this sense, to focus the research developed, it can be considered that the use of mobile devices has served more as an ICT resource than as a methodological approach to channel the experience. The methodological priority, in this case, is that of 
collaborative learning, but with the help of mobile devices, whose use can go beyond a work tool but to a transversal pedagogical approach.

\section{Justification and Research Objectives}

Roughly speaking, the new teaching scenario in higher education is characterized by the emergence of new challenges and trends in education, mainly derived from European policies that later were introduced in our current education Acts. Particularly, to introduce in our didactic processes these new regulations, we need to assume new methodological principles and didactic paradigms that enhance an active role for students and promote social and collaborative learning [78].

To contribute to the implementation of the necessary new methodology, along with this research, we present a pedagogical project based on the collaborative methodology to be implemented in the University Master's Degree in Compulsory Secondary Education and Baccalaureate, Vocational Training, and Language Teaching [79] through the use of mobile devices and taking into account the main mobile learning approaches in specific teaching modules [80,81].

Primarily, this will help us offer pre-service teachers the necessary tools to elaborate their didactic programs and participate actively in their school placements, making use of collaborative work and mobile learning. Especially in this University Degree, it seems convenient to teach students how to use mobile learning to foster the students' acquisition and promote the students' abilities to favor interaction $[82,83]$.

The main interest of our research is to know the effectiveness of the collaborative method concerning mobile learning, as opposed to the traditional methodology, in students of the University Master's Degree in Teaching of Compulsory Secondary Education and High School, Vocational Training, and Language Teaching, according to the learning of the didactic program.

Therefore, the following specific objectives are derived from the general objective: i) To specify the students' level of motivation, ii) to detect the level of interaction (teacher-student, student-student, student-content), iii) to find out the students' level of autonomy, iv) to find out the students' level of collaboration, v) to discover the level of deepening in the didactic contents, vi) Tt check the level in the resolution of problems in the didactic activities, vii) to know the level of classtime, and viii) to define the influence of the formative method through the qualifications.

\section{Methods}

\subsection{Research Design}

The research that we developed is based on a quantitative, correlational, and descriptive approach [84]; for this purpose, we applied a quasi-experimental design with a control group (CG) and experimental group (EG) using the design we proposed in previous research [85]. The students were divided into two groups; the experimental group developed a collaborative teaching methodology based on the use of mobile devices as a premise of an innovative pedagogical project, and the control group followed a traditional exhibition method, carried out throughout the academic year (Table 1). The technique of sampling for convenience was applied, since the distribution of students could not be carried out randomly.

Table 1. Groups' composition.

\begin{tabular}{cccccc}
\hline Group & $\mathbf{n}$ & Composition & Pretest & Treatment & Posttest \\
\hline 1. Control & 71 & Natural & - & $\mathrm{X}$ & $\mathrm{O}_{1}$ \\
2. Experimental & 67 & Natural & - & $\mathrm{X}$ & $\mathrm{O}_{2}$ \\
\hline
\end{tabular}

Additionally, two study variables were also defined. The dependent variable was related to the effects caused by the different academic indicators established in the research, while the independent variable was linked to the teaching and learning methodology applied in the study. Only one 
measurement was carried out, which was done at the end of the instructional process, through a research design that appeared only as a posttest.

\subsection{Participants}

As we have already stated, the study was carried out using a convenience sampling, consisting of 138 students. The students belong to a university in southern Spain and were currently in the University Master's Degree in Teaching of Compulsory Secondary Education and High School, Vocational Training, and Language Teaching. The participating students were $42.75 \%$ male and $57.25 \%$ female, aged between 21 and $54(\mathrm{M}=32, \mathrm{SD}=9.37)$, and were overall a total of $39.13 \%$ from the science branch and $60.87 \%$ from the humanities branch.

Note that, as indicated by the impact research we collected from the specialized literature review, the size of the sample is not a determining element for carrying out educational experiments in this type of study $[86,87]$.

We implemented the experience during the first semester of the 2019-2020 academic year, between 9 December 2019 and 20 December 2019. The students that participated in that period were previously informed about the research objectives and acknowledged the required information and permissions.

\subsection{Instruments}

To develop the research, we decided to collect data with an ad hoc questionnaire, mainly developed according to the different tools we selected from the literature review based on active teaching methodologies [88-92].

The questionnaire was articulated in nine main dimensions (Socio-educational, Motivation, Interactions, Autonomy, Collaboration, Deepening of contents, Problem-solving, Classtime, and Ratings) with 35 items with a response format based on a Likert scale (from $1=$ None to $4=$ Completely). In addition to the data collected in the questionnaire, the ratings provided by the teachers were also taken into consideration for the analysis (Appendix A).

To validate the questionnaire, we developed several processes. First of all, we used the Delphi qualitative validity method through the participation of ten experts, who evaluated it positively $(\mathrm{M}=4.74 ; \mathrm{SD}=0.23 ; \mathrm{min}=1)$. Then, Fleiss' Kappa statistics and Kendall's W were also applied to obtain the appropriate indicators $(\mathrm{K}=0.84 ; \mathrm{W}=0.83)$. Later on, it was quantitatively validated through an exploratory factorial analysis with varimax rotation focusing on positive results (Bartlett $=2547.51 ; \mathrm{p}<0.001 ;$ Kaiser-Meyer-Olkin $=0.86)$. Finally, Cronbach's alpha (0.86) and McDonald's omega method (0.85), the reliability of the compound (0.84), and the mean-variance extracted (0.82) were used, revealing adequate metrics. Hence, we could consider the necessary validity and reliability of the questionnaire.

\subsection{Study Dimensions}

To analyze the results, we delimited the different dimensions stated in the study. These dimensions were selected from the data that we got from previous research [88-92]. In general terms, the studies we refer to focus on the impact of certain independent variables on academic indicators:

- Socio-educational: It refers to items related to age, sex, nationality, religion, city, the students' course, and also some student-related issues.

- Motivation: It gathers items about the students' level of motivation.

- Interactions: It refers to the different forms of students' interaction (with other students, with the teacher, and with the academic agents) produced in the monitoring and tutoring time.

- Autonomy: It groups items about the level of autonomy the students achieve during the monitoring and tutoring.

- Collaboration: It refers to items about the students' teamwork.

- Depth in contents: It gathers items about the level of projection that the taught contents reached. 
- Problem-solving: It gathers items about the students' competence in solving problems that arise during the time of carrying out training practices.

- Classtime: It collects items related to the use of time in the training sessions that were given during the tutoring period.

- Ratings: It mentions items related to the students' ratings reached during the monitoring and tutoring period.

\subsection{Methodological Procedure}

The pedagogical project of this study followed several phases. Firstly, the sample was chosen in a specific educational center.

Later, we specified two pedagogical proposals to the proposed didactic program. On the one hand, there is the control group, which used a traditional method of exposure where the teacher reproduced the contents to be learned and where the students worked on the didactic program individually.

On the other hand, there is the experimental group, which developed a collaborative methodology and used mobile learning, carrying out the didactic program in pairs.

Finally, once the classes were over, we used the data collected through the questionnaire-previously validated - to proceed with the statistical analysis of the data to extract the results and conclusions of the study.

\subsection{Pedagogical Procedure}

The project was carried out in the "Educational processes and contexts" module of the University Master's Degree in Teaching of Compulsory Secondary Education and the Baccalaureate, Vocational Training, and Language Teaching. In particular, this module helps students to develop their teaching skills and abilities to create a didactic program.

In the experimental group, a collaborative teaching and mobile learning methodology was developed. The teaching program was developed in pairs. The teacher had previously established some guidelines for the development of such a didactic program through a virtual platform. Specifically, the virtual platform Prado2 was used, which is based on Moodle. During the development of the class, training activities related to the collaborative method were applied. A WhatsApp group was also created with the students, which served to resolve doubts. In this case, both the students and the teacher could answer. The teacher also took advantage of the Prado2 platform to control the entire process.

The total number of sessions for the subject "organization and management of educational centers" was 12. Each session lasted 2 hours. The sessions were structured in three parts: A first part in which a small debate was established, in which the theoretical contents of the Prado2 platform were analyzed; a second part in which dynamic and active activities were developed, related to the teaching methodology and the evaluation of the students; a third part in which the students carried out the didactic program in pairs. Throughout this process, the teacher acted as a guide of the pedagogical action, attending individually to the needs of the students. On the Prado2 platform, through the forums created, and in the WhatsApp group, once the session was over, a debate was established. The debate consisted of analyzing what had been done in class, making critical assessments. In addition, the students, using a digital portfolio, wrote down the activities developed and made a personal assessment of their work in the session and the activities proposed in the session.

In the control group, however, a traditional teaching methodology was developed through the explanations and theoretical presentations of the teacher. The students, in this case, had to prepare the didactic program of the subject individually, and raised their doubts in the class schedule to the teachers of the subject.

In short, the control group prepared a didactic program following a traditional teaching method, making the teacher use the exposition method. On the other hand, the experimental group, developed 
the didactic program by taking into account collaborative learning and making use of the mobile learning method, thanks to the use of the WhatsApp and Prado2 applications.

\subsection{Data Analysis}

Primarily, the data analysis was performed with IBM SPSS Statistics version 25.0. The statistics of the mean $(\mathrm{M})$, standard deviation $(\mathrm{SD})$, asymmetry $\left(\mathrm{A}_{\mathrm{me}}\right)$, and kurtosis $\left(\mathrm{K}_{\mathrm{me}}\right)$ were used for the descriptive study. Utilizing the Student $\mathrm{t}$-test, the comparison of means was carried out through the Student t-test for independent samples, resulting in the differences between the means of the experimental group and the control group. In both cases, a significant difference was estimated for values lower than $\mathrm{p}<0.05$, in addition to the $t$ statistics $\left(t_{n 1+n 2-2}\right)$, Cohen's $d$, and biserial correlation $\left(\mathrm{r}_{\mathrm{xy}}\right)$.

\section{Results}

The numbers shown in the descriptive statistical study of the students studying in the University Master's Degree in Teaching in Compulsory Secondary Education and High School, Vocational Training, and Language Teaching show very different data between the groups studied. On the one hand, the control group presents an average below two points, except in the autonomy, ratings, and teacher ratings dimensions, which are slightly above two. On the other hand, the experimental group presents measures higher than three in all of the dimensions of the study. In this case, the answers are medium-high. Taking into account Reference [93], which indicates that the values of asymmetry and kurtosis should be between +- 1.96, the distribution is normal in all of the dimensions studied. The standard deviation shows response dispersion in the control group, while in the experimental group, the response trend is more clustered. The kurtosis shown in all dimensions, both in the control group and in the experimental group, is platykurtic (Table 2).

Comparing the measures achieved by the control group and the experimental group, it can be seen that the total mean and the means of each of the dimensions are even, both in the control group and in the experimental group. There is no mean that stands out above the summed mean. The only two dimensions that stand out slightly are ratings and teacher ratings in the control group (Figure 1).

Table 2. Results obtained for the dimensions of study in GC and GE of Master of Teaching.

\begin{tabular}{|c|c|c|c|c|c|c|c|c|c|}
\hline & \multirow{2}{*}{ Dimensions } & \multicolumn{4}{|c|}{ Likert Scale $n(\%)$} & \multicolumn{4}{|c|}{ Parameters } \\
\hline & & None & Few & Enough & Completely & $\mathbf{M}$ & SD & $\mathrm{S}_{\mathrm{kw}}$ & $\mathbf{K}_{\mathrm{me}}$ \\
\hline \multirow{11}{*}{$\begin{array}{l}\text { Control } \\
\text { Group }\end{array}$} & Motivation & $32(45.1)$ & $16(22.5)$ & $17(23.9)$ & $6(8.5)$ & 1.96 & 1.02 & 0.585 & -0.959 \\
\hline & Teacher-student & $31(43.7)$ & $17(23.9)$ & $16(22.5)$ & $7(9.9)$ & 1.99 & 1.03 & 0.586 & -0.944 \\
\hline & Student-content & $33(46.5)$ & $15(21.1)$ & $15(21.1)$ & $8(11.3)$ & 1.97 & 1.06 & 0.635 & -0.966 \\
\hline & Student-student & $39(40.8)$ & $19(26.8)$ & $18(25.4)$ & $5(7)$ & 1.99 & 0.978 & 0.500 & -0.945 \\
\hline & Autonomy & $31(43.7)$ & $17(23.9)$ & 14(19.7) & $9(12.7)$ & 2.01 & 1.07 & 0.609 & -0.970 \\
\hline & Collaboration & $32(45.1)$ & $16(22.5)$ & $17(23.9)$ & $6(8.5)$ & 1.96 & 1.02 & 0.585 & -0.959 \\
\hline & Deepening & $35(49.3)$ & $13(18.3)$ & $15(21.1)$ & $8(11.3)$ & 1.94 & 1.08 & 0.673 & -0.972 \\
\hline & Resolution & $34(47.9)$ & $15(21.1)$ & $15(21.1)$ & $7(9.9)$ & 1.93 & 1.04 & 0.683 & -0.878 \\
\hline & Classtime & $37(52.1)$ & $12(16.9)$ & $18(25.4)$ & $4(5.6)$ & 1.85 & 0.995 & 0.679 & -0.955 \\
\hline & Ratings ${ }^{a}$ & $12(16.9)$ & $36(50.7)$ & $18(25.4)$ & $5(7)$ & 2.23 & 0.814 & 0.377 & -0.184 \\
\hline & Teacher ratings ${ }^{a}$ & 13(18.3) & $33(46.5)$ & $18(25.4)$ & $7(9.9)$ & 2.27 & 0.878 & 0.356 & -0.458 \\
\hline \multirow{11}{*}{$\begin{array}{c}\text { Experimental } \\
\text { Group }\end{array}$} & Motivation & $5(7.5)$ & 12(17.9) & $11(16.4)$ & $39(58.2)$ & 3.25 & 1.01 & -0.997 & -0.365 \\
\hline & Teacher-student & $6(9)$ & 13(19.4) & 10(14.9) & $38(59.7)$ & 3.19 & 1.04 & -0.891 & -0.664 \\
\hline & Student-content & $5(7.5)$ & $12(17.9)$ & $13(19.4)$ & $37(55.2)$ & 3.22 & 0.997 & -0.942 & -0.412 \\
\hline & Student-student & $5(7.5)$ & 12(17.9) & $14(20.9)$ & $36(53.7)$ & 3.21 & 0.993 & -0.916 & -0.431 \\
\hline & Autonomy & $8(9)$ & $11(16.4)$ & $12(17.9)$ & $38(56.7)$ & 3.22 & 1.02 & -0.987 & -0.380 \\
\hline & Collaboration & $5(7.5)$ & 11(16.4) & $14(20.9)$ & $37(55.2)$ & 3.24 & 0.986 & -0.992 & -0.264 \\
\hline & Deepening & $3(4.5)$ & 12(17.9) & $19(28.4)$ & $33(49.3)$ & 3.22 & 0.902 & -0.848 & -0.320 \\
\hline & Resolution & $3(4.5)$ & $11(16.4)$ & $19(28.4)$ & $34(50.7)$ & 3.25 & 0.893 & -0.924 & -0.142 \\
\hline & Classtime & $3(4.5)$ & $12(17.9)$ & $18(26.9)$ & $34(50.7)$ & 3.24 & 0.906 & -0.876 & -0.307 \\
\hline & Ratings $^{a}$ & $4(6)$ & $11(16.4)$ & 20(29.9) & $32(47.8)$ & 3.19 & 0.925 & -0.875 & -0.228 \\
\hline & Teacher ratings a & $2(3)$ & 11(16.4) & $18(26.9)$ & $36(53.7)$ & 3.31 & 0.857 & -0.959 & -0.114 \\
\hline
\end{tabular}




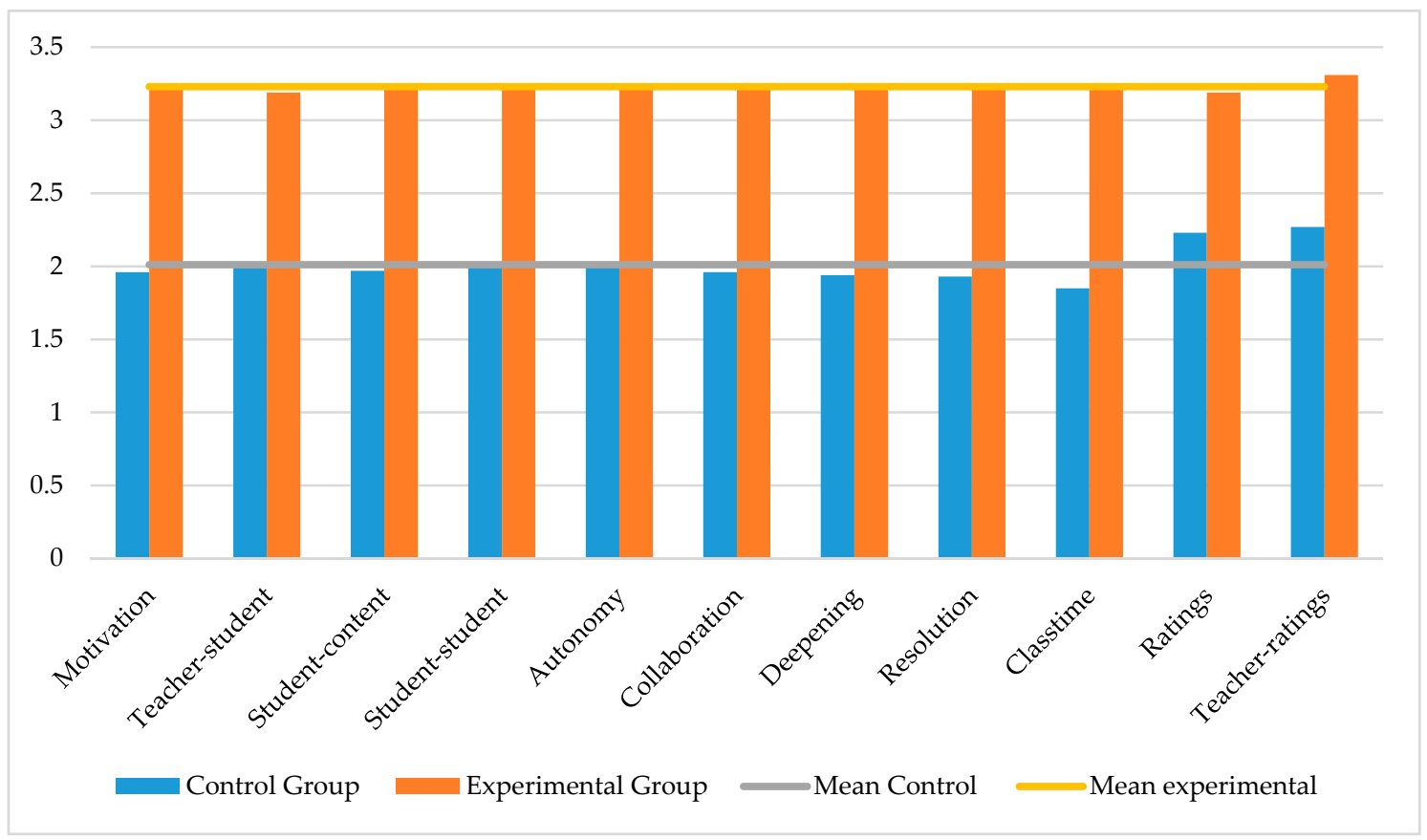

Figure 1. Comparison between control group and experimental group.

The degrees of independence of the results obtained in the teaching-learning method developed in the control group, in which a traditional teaching method was applied, and the pedagogical process of the experimental group, which developed a collaborative learning method associated with the use of mobile devices as a simplified mobile learning application, were identified thanks to the Student $t$ statistic for independence samples. The figures show a very significant relation in favor of the experimental group in all of the studied dimensions. The strength of association is average, according to the data provided by the biserial correlation. The effect size is low in all dimensions, except in student-student, autonomy, ratings, and teacher-ratings, which is very low (Table 3).

Table 3. Study of the value of independence between control group and experimental group.

\begin{tabular}{cccccc}
\hline Dimensions & $\boldsymbol{\mu}(\mathbf{X 1 - X 2 )}$ & $\boldsymbol{t}_{\boldsymbol{n} \mathbf{1 + n 2 - 2}}$ & $\mathbf{d f}$ & $\boldsymbol{d}$ & $\mathbf{r}_{\mathbf{x y}}$ \\
\hline Motivation & $-1.296(1.96-3.25)$ & $-7.511^{* *}$ & 136 & 0.108 & 0.541 \\
Teacher-student & $-1.208(1.99-3.19)$ & $-6.812^{* *}$ & 136 & 0.100 & 0.504 \\
Student-content & $-1.252(1.97-3.22)$ & $-7.105^{* *}$ & 136 & 0.117 & 0.520 \\
Student-student & $-1.223(1.99-3.21)$ & $-7.287^{* *}$ & 136 & 0.080 & 0.530 \\
Autonomy & $-1.210(2.01-3.22)$ & $-6.749^{* *}$ & 136 & 0.089 & 0.501 \\
Collaboration & $-1.281(1.96-3.24)$ & $-7.492^{* *}$ & 136 & 0.103 & 0.541 \\
Deepening & $-1.280(1.94-3.22)$ & $-7.533^{* *}$ & 136 & 0.144 & 0.543 \\
Resolution & $-1.324(1.93-3.25)$ & $-7.972^{* *}$ & 136 & 0.125 & 0.564 \\
Classtime & $-1.394(1.85-3.24)$ & $-8.588^{* *}$ & 136 & 0.159 & 0.593 \\
Ratings a & $-0.969(2.23-3.19)$ & $-6.539 * *$ & 136 & -0.075 & 0.489 \\
Teacher ratings $^{\text {a }}$ & $-1.046(2.27-3.31)$ & $-7.079 * *$ & 136 & -0.047 & 0.519 \\
\hline
\end{tabular}

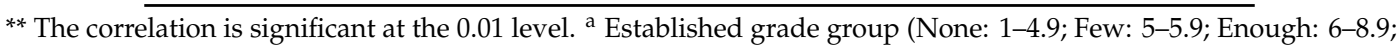
Completely: 9-10).

\section{Discussion}

Considering the new teaching scenario in the field of higher education, we as teachers have to face new challenges and trends to improve the teaching-learning processes. These innovations require a major change at all levels to offer the necessary training to be implemented later on with new applications and didactic methodologies that best fit this new teaching scenario [77]. Particularly, in the present-day society, the educational institutions must provide the necessary measures to contribute to 
the development of the didactic processes. Some good practices that educational institutions have started to promote refer to the creation of useful methodological principles that converge in a quality, current, and innovative education $[4,5,9]$.

Intending to focus on how all of these necessary changes in the teacher training can be best supported and implemented, along with this research, we restricted our attention to collaborative learning as a suitable methodology to be used in the teaching-learning processes. Hence, collaborative learning constitutes a good example of the necessary didactics and curricular re-adaptation required to be implemented in the syllabus design of the different modules of the University Master's Degree in Compulsory Secondary Education and Baccalaureate, Vocational Training, and Language Teaching.

Considering the research objectives, we may argue that the specific methodology for the training of pre-service teachers will help to achieve a better learning acquisition in the different didactic programs and modules of the University Master's Degree. Thus, we have exposed examples of how to provide continuity and support to school placements based on collaborative learning and the use of mobile devices. Even more, the results obtained showed that collaborative learning can be implemented in different didactic programs and modules because it favors learning in a transversal way.

It is convenient to observe that, due to the expansion of ICTs, mobile learning has been successfully implemented in the teaching modules of some degrees. It allows, among other aspects, real learning in a technological format. For this reason, it shows that the first research objective is achieved in that collaborative learning enhances the students' motivation and attitude towards learning.

Primarily, the key to selecting the methodological principles lies in the curricular elements to be achieved with the students. Based on this, the method is selected and, hence, the role the students will be assumed [11,26], as well as the skills to be worked on [21], the educational resources [15,19], and the exchanges of experience [25]. The importance of making a correct use of the methodology is a very important issue because, according to it, each student assumes a role and develops learning, and this has a direct impact on the rest of the group [29]. With regards to the research objectives, collaborative learning highly contributes to learning acquisition in comparison to traditional methodology.

The organization and development of group projects can encourage the joint resolution of problems [30], the holding of debates [31], or the creation of working groups [32]. These examples constitute a sample of the new socio-educational needs that we must assume; the role of the student becomes active, participative, and social, learning is significant and throughout life, and digital educational resources allow for constant interaction and dialogue. Moreover, these examples show how the levels of interaction between teacher-student, student-student, and student-content are extended, which means that dialogue and interaction increase as well as the development of the didactic process.

However, to achieve the teaching and learning processes with these innovative training lines, constant training of teachers is required [50], as well as a joint commitment and the development of joint actions by the educational community $[46,47]$. Related to the research objectives, we may say that, to achieve real collaborative learning, students need to develop a positive attitude towards learning, which implies that they show autonomy in learning, positive attitudes towards the level of collaboration they can create, and accept a positive assessment $[37,38]$, as well as that teachers assume a more active and participatory form [39]. The use of collaborative learning has also proved to be useful to the enhancement of classtime and the resolution of problems. As far as it favors interaction between teacher and student, it also helps in the resolution of problems and teaching guidance.

We would like to highlight the relevance of the students' motivation [41], the development of autonomy [42], and the attitude towards learning. ICTs allow educational innovation and enable and facilitate school management issues [51] up to the development of teaching processes in the current educational context $[49,50]$. The use of mobile devices, as a primary expression of mobile learning, is an example of educational innovation, allowing a connection between the real and the digital world [59], even encouraging study routines [60]. It offers new learning strategies through its resources, such as instant messaging [62,63], chatbots [64], and self-regulated learning [65]. The adaptation of mobile devices to learning makes it possible to offer up-to-date training that encourages interaction with 
the learner, the development of the emotional and social context, and an active role. The Mobile Computer-Supported Collaborative Learning (MCSCL) enables improvements in learning [66].

In this research, a pedagogical project based on collaborative learning was developed in the didactic modules through the use of mobile devices as an example of the potential of mobile learning, and therefore of the MCSCL $[80,81]$. The objective was to show how this specific methodology improves the training of pre-service teachers of the Master's Degree. The eight research objectives stated were fully developed and assumed, offering the discussion and the contributions to our research in this section.

On the other hand, the assessments given by the group of students in which the traditional teaching method for learning the didactic program was developed show a low tendency in all of the dimensions of the study, except in the grades given by the teachers of the subject and the self-evaluations given by the students. However, the ratings given by students who developed the collaborative learning teaching method associated with the use of mobile devices for learning the didactic program show a high valuation by the students.

If the data shown by the control group and the experimental group are compared, differences are observed in each of the nine dimensions (socio-educational, motivation, interactions, autonomy, collaboration, deepening of contents, problem-solving, classtime, and ratings), with a difference of approximately one point between the answers given by the two groups. The answers of the control group, in all of the dimensions, were even, which shows that the traditional method affects all of the studied elements in a similar way.

Note that only the grades given by the teachers and the students' self-evaluations stand out, although in a very superficial way. Significantly, the same happens with the responses of the experimental group, which were even. This also shows that the teaching method based on collaborative learning associated with mobile learning affects all dimensions equally.

This study also shows how the method has a direct impact on the rating, both in the control group and in the experimental group. It is relevant to focus on how the experimental group obtained better marks than the control group. All dimensions show a very high significance relationship. The greatest difference in average is observed in the feeling of time in the classroom. On the other hand, the smallest difference, although significant, is observed in the students' self-evaluations.

\section{Conclusions}

Roughly speaking, the research assumed presents solid knowledge on how collaborative learning associated with mobile learning is effective when teaching pre-service teachers the realization of didactic programs, as is reflected in the motivation, the relationship between teacher and student, the relationship between students and content, the relationship between student and student, in the autonomy in learning, the pedagogical collaboration between students, in the resolution of problems, in the sense of time in the training process, in the self-evaluation, and in the qualifications given by the teacher.

The prospect of this research is to show researchers the effects of the use of collaborative learning associated with the use of existing resources on mobile devices in the development of didactic programs for pre-service teachers. Hence, in this study, we exposed a new and effective pedagogical procedure to promote its use and utilization among teachers who develop didactic contents similar to those applied in this study. Furthermore, with this teaching method, we try to show a sustainable teaching model now. This is because this teaching method could be applied in confinement, allowing the student to adequately follow the teaching-learning process by making use of technological resources. 
The limitations of the study focus on several elements. On the one hand, the study population presents some specific characteristics and peculiarities, so one must be very careful when extrapolating the data collected here to other populations. On the other hand, access to the population was according to convenience, and it was not possible to apply some sampling techniques in the development of this study due to the difficulties that exist for access to these types of groups. Finally, the method and data collection involved a considerable effort for the researchers, given that they had to train the teachers in charge of applying these teaching and learning methods, in addition to monitoring the process, collecting the data, and processing that data for their study.

The future lines of research focus on developing this teaching and learning procedure in other contents and in other subjects of the University Master's Degree in Compulsory Secondary Education and Baccalaureate, Vocational Training, and Language Teaching to ascertain its viability in other types of content. At the same time, it would also be an interesting avenue of research to apply this type of approach to a broader mobile learning methodology that is not solely focused on the use of a resource available on mobile devices.

Author Contributions: Conceptualization, P.L.O., A.-J.M.-G., and M.M.M.; methodology, M.M.M. and P.L.O.; software, A.-J.M.-G. and P.L.O.; validation, A.-J.M.-G.; formal analysis, R.S.C.; investigation, M.M.M., A.-J.M.-G., R.S.C., and P.L.O.; data curation, A.-J.M.-G., M.M.M., and R.S.C.; writing-original draft preparation, M.M.M., A.-J.M.-G., R.S.C., and P.L.O.; writing-review and editing, M.M.M., A.-J.M.-G., R.S.C., and P.L.O.; visualization R.S.C.; supervision, M.M.M. and P.L.O. All authors have read and agreed to the published version of the manuscript.

Funding: This research received no external funding.

Acknowledgments: We acknowledge the researchers of the research group AREA (HUM-672), which belongs to the Ministry of Education and Science of the Junta de Andalucía and is registered in the Department of Didactics and School Organization of the Faculty of Education Sciences of the University of Granada.

Conflicts of Interest: The authors declare no conflict of interest.

\section{Appendix A Collaborative Learning Questionnaire}

Table A1. Collaborative Learning Questionnaire.

\begin{tabular}{|c|c|c|c|c|}
\hline Variable & No. & Item & Choice & $\sqrt{ }$ \\
\hline \multirow{2}{*}{ Gender } & \multirow{2}{*}{1} & \multirow{2}{*}{ Gender } & Boy & \\
\hline & & & Girl & \\
\hline Age & 2 & Age & (Specify):_ _ _ _ _ _ & \\
\hline City & 3 & Place of residence & (Specify): _. . . . . _ & \\
\hline Nationality & 4 & Nationality & (Specify):_ _. . . . . & \\
\hline \multirow{6}{*}{ Religion } & \multirow{6}{*}{5} & \multirow{6}{*}{ Religion } & Christian & \\
\hline & & & Muslim & \\
\hline & & & Jewish & \\
\hline & & & Hindu & \\
\hline & & & Atheist & \\
\hline & & & Other & \\
\hline Course & 6 & Academic course & (Specify): _. . . . . . & \\
\hline \multirow{2}{*}{ Course Repeat } & \multirow{2}{*}{7} & \multirow{2}{*}{ Have you ever repeated a course? } & Yes & \\
\hline & & & No & \\
\hline \multirow{2}{*}{ Learning difficulty } & \multirow{2}{*}{8} & \multirow[t]{2}{*}{ Do you have any learning difficulties? } & Yes: _ _ _ . . . & \\
\hline & & & No & \\
\hline
\end{tabular}


Table A1. Cont.

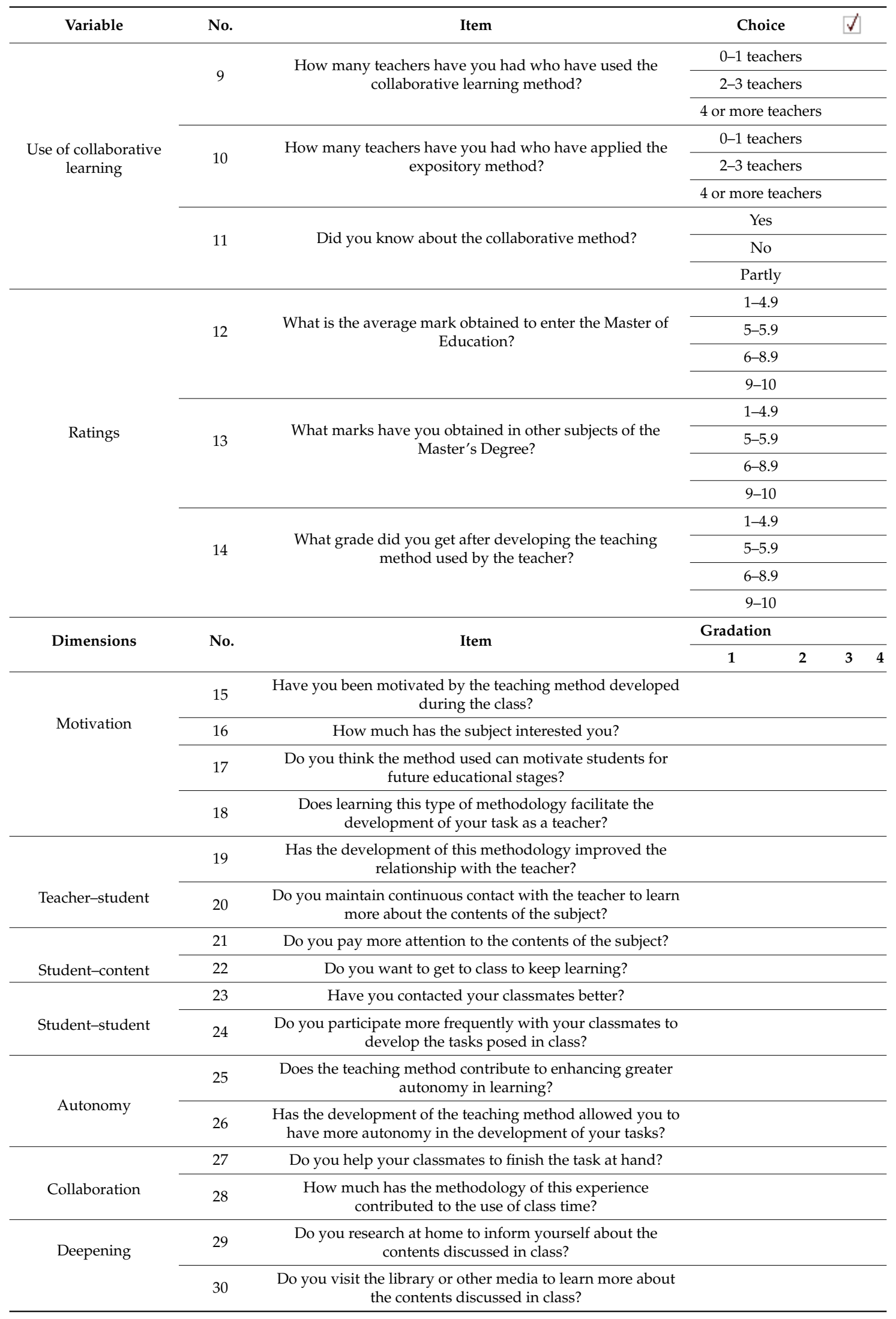


Table A1. Cont.

\begin{tabular}{|c|c|c|c|c|}
\hline Variable & No. & Item & Choice & $\sqrt{ }$ \\
\hline \multirow{2}{*}{ Resolution } & 31 & $\begin{array}{l}\text { Does the teaching method allow you to solve the doubts you } \\
\text { have during the development of the contents? }\end{array}$ & & \\
\hline & 32 & $\begin{array}{l}\text { Does the teaching method facilitate the resolution of the tasks } \\
\text { you have to develop during the classes? }\end{array}$ & & \\
\hline \multirow{3}{*}{ Classtime } & 33 & Time in class passes very quickly & & \\
\hline & 34 & I am not aware of the time when I'm in class & & \\
\hline & 35 & $\begin{array}{l}\text { When I finish the class, I do not feel fatigued or tired by the } \\
\text { development of the subject. }\end{array}$ & & \\
\hline
\end{tabular}

\section{References}

1. Kars-Unluoglu, S. How do we educate future innovation managers? Insights on innovation education in MBA syllabi. Innov. Manag. Policy Pract. 2016, 18, 74-98. [CrossRef]

2. Goolsarran, N.; Hamo, C.E.; Lu, W.H. Using the jigsaw technique to teach patient safety. Med Educ. Online 2020, 25, 1710325. [CrossRef] [PubMed]

3. Supermane, S. Transformational leadership and innovation in teaching and learning activities: The mediation effect of knowledge management. Inf. Discov. Deliv. 2019, 47, 242-250. [CrossRef]

4. Killen, C.P. Three dimensions of learning: Experiential activity for engineering innovation education and research. Eur. J. Eng. Educ. 2015, 40, 476-498. [CrossRef]

5. Li, G.; Wang, F. Research on art innovation teaching platform based on data mining algorithm. Clust. Comput. J. Neteworks Softw. Tools Appl. 2019, 22, 13867-13872. [CrossRef]

6. Ho, P.A.; Girgis, C.; Rustad, J.K.; Noordsy, D.; Stern, T.A. Advancing the mission of consultation-liaison psychiatry through innovation in teaching. Psychosomatics 2019, 60, 539-548. [CrossRef]

7. Soltis, N.A.; McNeal, K.S.; Forbes, C.T.; Lally, D. The relationship between active learning, course innovation, and teaching Earth systems thinking: A structural equation modeling approach. Geosphere 2019, 15, 1703-1721. [CrossRef]

8. Luque, A.M. Ways of otherness in an institutional history teaching innovation experiences for jurists and political scientist. E-Leg. Hist. Rev. 2019, 30, 1-20.

9. Beekman, M.; Emani, V.K.; Wolford, R.; Hanson, K.; Wickham, G.; Aiyer, M. Patient safety morning report: Innovation in teaching core patient safety principles to third-year medical students. J. Med Educ. Curric. Dev. 2019, 6. [CrossRef]

10. Bravo, M.J.; Ortuno, M.A.; Valmana, A.; Vizcaino, J.; Rodríguez, R.; Ruiz, M.E.; Salazar, M.; Vallejo, G.; Osaba, M.E. IVRA: Romans, Visigoths and Byzantines. An experience of teaching innovation in the key of gender. Revista de Educacion y Derecho 2019, 20. [CrossRef]

11. Hofmann, R.; Mercer, N. Teacher interventions in small group work in secondary mathematics and science lessons. Lang. Educ. 2016, 30, 400-416. [CrossRef]

12. Salas-Rueda, R.A. Use of the TPACK model as an innovation tool for the teaching-learning process on mathematics. Perspect. Educ. 2018, 57, 3-26.

13. López, D.; Calonge, A.; Rodríguez, T.; Ros, G.; Lebron, J.A. Using gamification in a teaching innovation project at the university of Alcala: A new approach to experimental science practices. Electron. J. E Learn. 2019, 17, 93-106.

14. López, J.; Fuentes, A.; López, J.A.; Pozo, S. Formative transcendence of flipped learning in mathematics students of secondary education. Mathematics 2019, 7, 1226. [CrossRef]

15. Zhang, S.; Wen, Y.; Liu, Q. Exploring student teachers? social knowledge construction behaviors and collective agency in an online collaborative learning environment. Interact. Learn. Environ. 2019. [CrossRef]

16. Kerhani, P.; Kaveh, M.H.; Faghih, S.; Salehi, M. Improving diet quality among adolescents, using health belief model in a collaborative learning context: A randomized field trial study. Health Educ. Res. 2019, 34, 279-288.

17. Falcione, S.; Campbell, E.; McCloumm, B.; Chamberlain, J.; Macias, M.; Morsch, L.; Pinder, C. Emergence of different perspectives of success in collaborative learning. Can. J. Scholarsh. Teach. Learn. 2019, 10. [CrossRef]

18. Zambrano, R.J.; Kirschner, F.; Sweller, J.; Kirschner, P.A. Effects of prior knowledge on collaborative and individual learning. Learn. Instr. 2019, 63, 1012014. [CrossRef] 
19. Acosta, R.; Martín-García, A.V.; Hernández, A. Use of the collaborative learning methodologies with ICT: An analysis based on the teachers' beliefs. Digit. Educ. Rev. 2019, 35, 309-323.

20. Van Leeuwen, A.; Janssen, J. A systematic review of teacher guidance during collaborative learning in primary and secondary education. Educ. Res. Rev. 2019, 27, 71-89. [CrossRef]

21. Zambrano, R.J.; Kirschner, F.; Sweller, J.; Kirschner, P.A. Effects of group experience and information distribution on collaborative learning. Instr. Sci. 2019, 47, 531-550. [CrossRef]

22. Meijer, H.; Hoekstra, R.; Brouwer, J.; Strijbos, J.W. Unfolding collaborative learning assesment literacy: A reflection on current assesment methods in higher education. Assess. Eval. High. Educ. 2020. [CrossRef]

23. Isohatala, J.; Naykki, P.; Jarvela, S. Cognitive and socio-emotional interaction in collaborative learning: Exploring fluctuations in students' participation. Scand. J. Educ. Res. 2019. [CrossRef]

24. Alghasab, M.; Hardman, J.; Handley, Z. Teacher-student interaction on wikis: Fostering collaborative learning and writing. Learn. Cult. Soc. Interact. 2019, 21, 10-20. [CrossRef]

25. Volet, S.; Seghezzi, C.; Ritchie, S. Positive emotions in student-led collaborative science activities: Relating types and sources of emotions to engagement in learning. Stud. High. Educ. 2019, 44, 1734-1746. [CrossRef]

26. Chan, S.C.H.; Wan, C.L.J.; Ko, S. Interactivity, active collaborative learning, and learning performance: The moderating role of perceived fun by using personal response system. Int. J. Manag. Educ. 2019, 17, 94-102. [CrossRef]

27. Bers, M.U.; González-González, C.; Armas-Torres, U. Coding as a playground: Promoting positive learning experiences in childhood classrooms. Comput. Educ. 2019, 138, 130-145. [CrossRef]

28. Voupala, E.; Naykki, P.; Isohatala, J.; Jarvela, S. Knowledge co-construction activities and task-related monitoring in scripted collaborative learning. Learn. Cult. Soc. Interact. 2019, 21, 234-249. [CrossRef]

29. Maqtary, N.; Mohsen, A.; Bechkoum, K. Group formation techniques in computer-supported collaborative learning: A systematic literature review. Technol. Knowl. Learn. 2019, 24, 169-190. [CrossRef]

30. Jung, J.; Shin, Y.; Zumbach, J. The effects of pre-training types on cognitive load, collaborative knowledge construction and deep learning in a computer-supported collaborative learning environment. Interact. Learn. Environ. 2019. [CrossRef]

31. Boulton, H. Crossing boundaries: The affordances of new technologies in supporting a collaborative learning environment for doctoral students learning transnationally. Technol. Pedagog. Educ. 2019, 28, 255-267. [CrossRef]

32. Hirsh, A.; Segolsson, M. Enabling teacher-driven school-development and collaborative learning: An activity theory-based study of leadership as an overarching practice. Educ. Manag. Adm. Leadersh. 2019, 47, 400-420. [CrossRef]

33. Wilson, K.F.; Wilson, K. Collaborate to graduate? What works and why? High. Educ. Res. Dev. 2019, 38, 1504-1518. [CrossRef]

34. Chatterjee, R.; Correia, A.P. Online students' attitudes toward collaborative learning and sense of community. Am. J. Distance Educ. 2020, 24, 53-68. [CrossRef]

35. Schnaubert, L.; Bodemer, D. Providing different types of group awareness information to guide collaborative learning. Int. J. Comput. Support. Collab. Learn. 2019, 14, 7-51. [CrossRef]

36. Williams, E.A.; Zwolak, J.P.; Dou, R.; Brewe, E. Linking engagement and performance: The social network analysis perspective. Phys. Rev. Phys. Educ. Res. 2019, 15, 020150. [CrossRef]

37. Zhang, X.; Meng, Y.; Ordóñez, P.; Sun, Y. Learning analytics in collaborative learning supported by Slack: From the perspective of engagement. Comput. Hum. Behav. 2019, 92, 625-633. [CrossRef]

38. Hautala, J.; Schmidt, S. Learning across distances: An international collaborative learning project between Berlin and Turku. J. Geogr. High. Educ. 2019, 43, 181-200. [CrossRef]

39. Gomez, L.F. Intention and pedagogical competence: Use of collaborative learning in the subject of mathematics in secondary school. Propósitos y Represent. 2016, 4, 157-179.

40. Hargreaves, E.; Elhawary, D.; Mahgoub, M. 'One girl had a different idea's: Children's perspectives on learning and teaching models in the traditional classroom. Education 2020, 48, 87-99.

41. Simons, M.; Baeten, M.; Vanhees, C. Team teaching during field experiences in teacher education: Investigating student teachers' experiences with parallel and sequential teaching. J. Teach. Educ. 2020, 71, 24-40. [CrossRef]

42. Troussas, C.; Krouska, A.; Sgouropoulou, C. Collaboration and fuzzy-modeled personalization for mobile game based learning in higher education. Comput. Educ. 2020, 144, 1-18. [CrossRef] 
43. Rojprasert, S.; Neanchaleay, J.; Boonlue, S.; Sinlarat, P. Designing and implementing constructionist learning in a blended advertising photography course. Int. J. Technol. Enhanc. Learn. 2020, 12, 20-37. [CrossRef]

44. Asino, T.I.; Pulay, A. Student perceptions on the role of the classroom environment on computer Supported collaborative learning. Techtrends 2019, 63, 179-187. [CrossRef]

45. Tissenbaum, M. I see what you did there! Divergent collaboration and learner transitions from unproductive to productive states in open-ended inquiry. Comput. Educ. 2020, 145, 1-15. [CrossRef]

46. Domingo-Coscollola, M.; Bosco, A.; Carrasco, S.; Sánchez, J.A. Fostering teacher's digital competence at university: The perception of students and teachers. RIE 2020, 38, 167-182. [CrossRef]

47. Sung, Y.T.; Yang, J.M.; Lee, H.Y. The Effects of mobile-computer-supported collaborative learning: Meta-analysis and crytical synthesis. Rev. Educ. Res. 2017, 87, 768-805. [CrossRef]

48. Grant, M. Difficulties in defining mobile learning: Analysis, design characteristics, and implications. Educ. Technol. Res. Dev. 2019, 67, 361-388. [CrossRef]

49. Chung, C.; Hwang, G.; Lai, C. A review of experimental mobile learning research in 2010-2016 based on the activity theory framework. Comput. Educ. 2019, 129, 1-13. [CrossRef]

50. Hsieh, Y.C. Learner interactions in face-to-face collaborative writing with the support of online resources. RECALL 2020, 32, 85-105. [CrossRef]

51. Suartama, I.K.; Setyosari, P.; Sulthoni, S.; Ulfa, S. Development of an instructional design mobile blended learning in higher education. Int. J. Emerg. Technol. Learn. 2019, 14, 4-22. [CrossRef]

52. Bai, H. Pedagogical practices of mobile learning in k-12 and higher education settings. Techtrends 2019, 63, 611-620. [CrossRef]

53. Chou, C.M.; Shen, C.H.; Hsiao, H.C.; Shen, T.C. Factors influencing teachers' innovative teaching behaviour with information and communication technology (ICT): The mediator role of organisational innovation climate. Educ. Psychol. 2019, 39, 65-85. [CrossRef]

54. Campos, N.; Ramos, M.; Moreno, A.J. Virtual reality and motivation in the educational context: Bibliometric study of the last twenty years from Scopus. Alteridad. Rev. De Educ. 2020, 15, 47-60.

55. Androutsos, A.; Brinia, V. Developing and piloting a pedagogy for teaching innovation, collaboration, and Co-creation in secondary Education based on design thinking, digital transformation, and entrepreneurship. Educ. Sci. 2019, 9, 113. [CrossRef]

56. Van Assche, N.; Fickl, S.; Francisco, H.; Gurzawska, K.; Milinkovic, I.; Navarro, J.M.; Torsello, F.; Thoma, D.S. Guidelines for development of Implant Dentistry in the next 10 years regarding innovation, education, certification, and associations. Clin. Oral Implant. Res. 2018, 29, 568-575. [CrossRef]

57. Bond, M.; Buntins, K.; Bedenlier, S.; Zawacki, O.; Kerres, M. Mapping research in student engagement and educational technology in higher education: A systematic evidence map. Int. J. Educ. Technol. High. Educ. 2020, 17, 2. [CrossRef]

58. Sun, H. Dataset of mobile learning effectiveness on learning computer programming in community college. Data Brief 2019, 26, 104525.

59. Crompton, H.; Burke, D.; Gregory, K.H. The use of mobile learning in PK-12 education: A systematic review. Comput. Educ. 2017, 110, 51-63. [CrossRef]

60. Danish, J.; Hmelo-Silver, C.E. On activities and affordances for mobile learning. Contemp. Educ. Psychol. 2020, 60, 101829. [CrossRef]

61. Xie, K.; Heddy, B.C.; Greene, B.A. Affordances of using mobile technology to support experience-sampling method in examining college students' engagement. Comput. Educ. 2019, 128, 183-198. [CrossRef]

62. So, S. Mobile instant messaging support for teaching and learning in higher education. Internet High. Educ. 2016, 31, 32-42. [CrossRef]

63. Pimmer, C.; Brühlmann, F.; Odetola, T.D.; Oluwasola, D.O.; Dipeolu, O.; Ajuwon, A.J. Facilitating professional mobile learning communities with instant messaging. Comput. Educ. 2019, 128, 102-112. [CrossRef]

64. Smutny, P.; Schreiberova, P. Chatbots for learning: A review of educational chatbots for the Facebook Messenger. Comput. Educ. 2020, 151, 103862. [CrossRef]

65. Jansen, R.S.; Van Leeuwen, A.; Janssen, J.; Jak, S.; Kester, L. Self-regulated learning partially mediates the effects of self-regulated interventions on achievement in higher education: A meta-analysis. Educ. Res. Rev. 2019, 28, 100292. [CrossRef]

66. Aznar, I.; Reche, M.P.C.; Rodríguez, J.M.R. Quality indicators to evaluate good teaching practices of mobile learning in higher education. Educ. Knowl. Soc. 2018, 19, 53-68. 
67. Sung, Y.T.; Lee, H.Y.; Yang, J.M.; Chang, K.E. The quality of experimental designs in mobile learning research: A systemic review and self-improvement tool. Educ. Res. Rev. 2019, 28. [CrossRef]

68. Kim, H.J.; Lee, J.M.; Rha, J.Y. Understanding the role of user resistance on mobile learning usage among university students. Comput. Educ. 2017, 113, 108-118. [CrossRef]

69. Lim, G.; Shelley, A.; Heo, D. The regulation of learning and co-creation of new knowledge in mobile learning. Knowl. Manag. E Learn. 2019, 11, 449-484.

70. Chang, C.Y.; Lai, C.L.; Hwang, G.J. Trends and research issues of mobile learning studies in nursing education: A review of academic publications from 1971 to 2016. Comput. Educ. 2018, 116, 28-48. [CrossRef]

71. Chee, K.N.; Yahaya, N.; Ibrahim, N.; Hasan, M. Review of mobile learning trends 2010-2015: A meta-analysis. Educ. Technol. Soc. 2017, 20, 113-126.

72. Zheng, L.; Zhang, X.; Gyasi, J.F. A literature review of features and trends of technology-supported collaborative learning in informal learning settings from 2007 to 2018. J. Comput. Educ. 2019, 6, 529-561. [CrossRef]

73. Diab, M.H.; Boticki, I.; Hoic-Bozic, N.; Looi, C.K. Exploring group interactions in synchronous mobile computer-supported learning activities. Comput. Educ. 2020, 146, 103735.

74. Fu, Q.; Hwang, G.J. Trends in mobile technology-supported collaborative learning: A systematic review of journal publications from 2007 to 2016. Comput. Educ. 2018, 119, 129-143. [CrossRef]

75. Jeong, H.; Hmelo-Silver, C.; Jo, K. Ten years of computer-supported collaborative learning: A meta-analysis of CSCL in STEM education during 2005-2014. Educ. Res. Rev. 2019, 28, 100284. [CrossRef]

76. Chen, J.; Wang, M.; Kirschner, P.A.; Tsai, C.C. A meta-analysis examining the moderating effects of educational level and subject área on CSCL effectiveness. Knowl. Manag. E-Learn. Int. J. 2019, 11, 409-427.

77. Martínez, S. Teaching innovation projects: Fundamental features to their on design, implementation and evaluation. Revista Ciencias Pedagógicas e Innovación 2019, 7, 95-103.

78. Moreno-Guerrero, A.J. Estudio bibliométrico de la producción científica sobre la inspección educativa. REICE Revista Iberoamericana sobre Calidad, Eficacia y Cambio en Educación 2019, 17, 23-40. [CrossRef]

79. Hinojo, F.J.; Aznar, I.; Romero, J.M.; Marín, J.A. Influencia del aula invertida en el rendimiento académico. Una revisión sistemática. Campus Virtuales 2019, 8, 9-18.

80. Sola, T.; Aznar, I.; Romero, J.M.; Rodríguez, A.M. Eficacia del método flipped classroom en la universidad: Meta-análisis de la producción científica de impacto. REICE Revista Iberoamericana sobre Calidad, Eficacia y Cambio en Educación 2019, 17, 25-38. [CrossRef]

81. Moreno-Guerrero, A.J. Estudio bibliométrico de la producción científica en web of science: Formación profesional y blended learning. Píxel Bit Revista de Medios y Educación 2019, 56, 149-168. [CrossRef]

82. Moreno-Guerrero, A.J.; Rondón, M.; Martínez, N.; Rodríguez-García, A.M. Collaborative learning based on Harry Potter for learning geometric figures in the subject of mathematics. Mathematics 2020, 8, 369. [CrossRef]

83. Moreno-Guerrero, A.J.; Rodríguez-Jiménez, C.; Gómez-García, G.; Ramos, M. Educational innovation in higher education: Use of role playing and educational video in pre-service teachers' training. Sustainability 2020, 12, 2558. [CrossRef]

84. Hernández, R.; Fernández, C.; Baptista, M.P. Metodología de la Investigación, 6th ed.; McGraw Hill: Madrid, Spain, 2014; pp. 129-168.

85. Pozo, S.; López, J.; Moreno-Guerrero, A.J.; López, J.A. Impact of educational stage in the application of flipped learning: A contrasting analysis with traditional teaching. Sustainability 2019, 11, 5968. [CrossRef]

86. Chou, P.N.; Feng, S.T. Using a tablet computer application to advance high school students' laboratory learning experiences: A focus on electrical engineering education. Sustainability 2019, 11, 381. [CrossRef]

87. Yilmaz, A.; Soyer, F. Effect of physical education and play applications on school social behaviors of mild-level intellectually disabled children. Educ. Sci. 2018, 8, 89. [CrossRef]

88. Driscoll, T. Flipped Learning and Democratic Education. Bachelor's Thesis, Columbia University, New York, NY, USA, 2012.

89. Moreno-Guerrero, A.J.; Romero-Rodríguez, J.M.; López-Belmonte, J.; Alonso-García, S. Flipped learning approach as educational innovation in water literacy. Water 2020, 12, 574. [CrossRef]

90. López, J.A.; López, J.; Moreno-Guerrero, A.J.; Pozo, S. Effectiveness of innovate educational practices with flipped learning and remote sensing in earth and environmental sciences-A case study. Remote Sens. 2020, 12, 897. [CrossRef] 
91. Santiago, R.; Bergmann, J. Aprender al Revés, 1st ed.; Paidós Educación: Barcelona, Spain, 2018; pp. $133-142$.

92. Sánchez-Pérez, M. Teacher Training for English-Medium Instruction in Higher Education, 1st ed.; IGI Global: Hershey, PA, USA, 2020; pp. 223-249.

93. Jöreskog, K.G. Analysis of ordinal variables 2: Cross-Sectional Data. In Structural Equation Modelling with Lisrel 8.51; Friedrich-Schiller-University Jena: Jena, Germany, 2001; pp. 116-119.

(C) 2020 by the authors. Licensee MDPI, Basel, Switzerland. This article is an open access article distributed under the terms and conditions of the Creative Commons Attribution (CC BY) license (http://creativecommons.org/licenses/by/4.0/). 